\title{
Morphometric and molecular characterization of the species of Uncinaria Frölich, 1789 (Nematoda) parasitic in the Australian fur seal Arctocephalus pusillus doriferus (Schreber), with notes on hookworms in three other pinniped hosts
}

\section{Paul Ramos • Michael Lynch • Min Hu • John P.Y. Arnould ・ Richard Norman • Ian Beveridge}

Received: 12 November 2012 / Accepted: 25 January 2012

\begin{abstract}
This study presents morphological and molecular data on hookworms from the Australian fur seal Arctocephalus pusillus doriferus (Schreber) currently identified in Australian waters as Uncinaria hamiltoni Baylis, 1933. Additional specimens from the Australian sea lion Neophoca cinerea (Péron) and the New Zealand fur seal Arctocephalus forsteri (Lesson) from Australia, and the Southern elephant seal Mirounga leonina (Linnaeus) from Antarctica, were included. Using the internal transcribed spacer (ITS), hookworms from A. p. doriferus, N. cinerea and A. forsteri were found to be genetically similar but distinct from Uncinaria spp. found in M. leonina from Antarctica, as well as from Zalophus californianus (Lesson) and Callorhinus ursinus (Linnaeus) from California. Few morphological differences were detected between these taxa.
\end{abstract}

P. Ramos ( $\square)$

Zoos Victoria, PO Box 74, Parkville, Victoria 3052, Australia

e-mail: pramos.vet@gmail.com

M. Lynch

Zoos Victoria, PO Box 74, Parkville, Victoria 3052, Australia

M. Hu

School of Veterinary Science, University of Melbourne, 250 Princes Highway, Werribee, Victoria 3030, Australia current address: State Key Laboratory of Agricultural Microbiology, College of Veterinary Medicine, Huazhong Agricultural University, 1 Shizishan St., Wuhan, 430070 Hubei, P. R. China

J. P. Y. Arnould 
School of Life \& Environmental Sciences, Deakin University, 221 Burwood Highway, Burwood, Victoria 3125 , Australia

\section{R. Norman}

School of Veterinary Science, University of Melbourne, 250 Princes Highway, Werribee, Victoria 3030, Australia current address: Ministry for Primary Industries, Investigation and Diagnostic Centres and Response, PO Box 2526, Wellington 6140, New Zealand

I. Beveridge

e-mail: ibeve@unimelb.edu.au

School of Veterinary Science, University of Melbourne, 250 Princes Highway, Werribee, Victoria 3030, Australia

\section{Introduction}

The taxonomy of the species of Uncinaria Frölich, 1789 (Nematoda: Ancylostomatidae) found in pinnipeds is unclear. Historically, two species of hookworms of pinnipeds have been described, namely Uncinaria lucasi Stiles, 1901 from the Northern fur seal Callorhinus ursinus (Linnaeus) in Alaska (Olsen \& Lyons, 1965) and Uncinaria hamiltoni Baylis, 1933 from the South American sea lion Otaria byronia (Shaw) on the Falkland Islands (Baylis, 1933). Variations in parasite morphology, pathogenicity and life history (Baylis, 1947; Dailey \& Hill, 1970; Sepulveda \& Alcaino, 1993; Lyons et al., 2000; Beron-Vera et al., 2004; Spraker et al., 2007) have however led to speculation that there may be more than two species. An alternative view is that such variation arises through disparities in environmental influences and that all pinniped hookworms belong to a single species, U. lucasi (see George-Nascimento et al., 1992). Recent studies utilizing molecular techniques support the viewpoint that a greater number of distinct species exists (Nadler et al., 2000; Lyons et al., 2011).

Subsequent to the initial descriptions of the named hookworm species, there have been additional reports, largely focused on morphometric comparisons, from several other host species (Johnston \& Mawson, 1945; Dailey \& Hill, 1970; George-Nascimento et al., 1992; Sepulveda \& Alcaino, 1993; Lyons et al., 1997; Sepulveda, 1998; Beron-Vera et al., 2004). Infections with $U$. lucasi have been described in the Northern fur seal populations from San Miguel Island, California and the Pribilof Islands, Alaska (Lucas, 1899; Lyons et al., 2011); there are also reports from the Steller sea lion Eumetopias jubatus (Schreber) in Alaska (Olsen, 1958), the South American sea lion O. byronia (syn. O. flavescens Shaw, see Oliva, 1988) in Chile and Uruguay (George-Nascimento et al., 1992) and the South American fur seal Arctocephalus australis (Zimmermann) in Uruguay. Hookworms from the California sea lion 
Zalophus californianus (Lesson) on San Miguel Island, California are currently described as Uncinaria species A (Lyons et al., 2011).

$U$. hamiltoni has been documented only in the southern hemisphere from O. byronia in Argentina (Beron-Vera et al., 2004), the Falkland Islands (Baylis, 1947) and Uruguay (Botto \& Mane-Garzon, 1975), the Australian sea lion Neophoca cinerea (Péron) in South Australia (Beveridge, 1980) and the Southern elephant seal Mirounga leonina (Linnaeus) on the Crozet Islands (Johnston \& Mawson, 1945). Hookworms found in the Juan Fernandez fur seal Arctocephalus philippii (Peters) in Chile and the New Zealand sea lion Phocarctos hookeri (Grey) in New Zealand are currently referred to as Uncinaria spp. (Sepulveda, 1998; Castinel et al., 2006).

Hookworms found in otariid seals of southern Australian and New Zealand waters are morphologically most similar to U. hamiltoni (see Beveridge, 1980; Castinel et al., 2006). The aim of this study is to describe the hookworm species infecting the Australian fur seal Arctocephalus pusillus doriferus (Schreber) through the application of morphological and molecular methods, and to compare the novel data with existing reports.

\section{Materials and methods}

\section{Morphological study}

Parasites were collected during post mortem examination of nine freshly dead A. p. doriferus

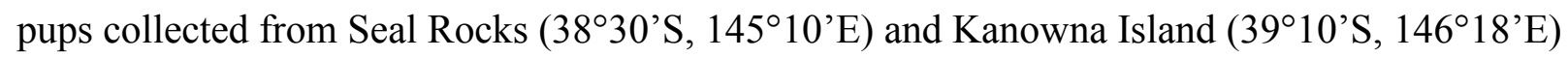
in south-eastern Australia. Field trips were conducted in 2007 and 2008 and a total of twenty (7 male and 13 female) specimens of Uncinaria were obtained and stored in 10\% formalin for morphological studies. In addition, specimens of Uncinaria collected from other southern pinnipeds were available for this study. The host species and locations are as follows: $N$. cinerea (collected by R. Norman, 1993, Dangerous Reef, 3449'S, $136^{\circ} 13^{\prime} \mathrm{E}$, and Kangaroo Island $36^{\circ} 04^{\prime} \mathrm{S}, 136^{\circ} 42^{\prime} \mathrm{E}$, South Australia), Arctocephalus forsteri (Lesson) (collected by R. Norman, 1993, Kangaroo Island, South Australian Museum (SAM) 46152), and M. leonina (collected by T.H. Johnson, BANZARE expedition 1929-1931, Possession Island, 46²5’S, 51 ${ }^{\circ} 45^{\prime} \mathrm{E}$, SAM 34996). Only one male and one female specimen from A. forsteri and one male specimen from M. leonina were available for analysis.

Specimens were cleared in lactophenol and examined using light microscopy. The heads and tails, retained as voucher specimens from the worms used in the molecular study, were also included in the morphological study. The following measurements (in millimetres unless 
otherwise stated) were taken: BL, body length; MBW, maximum body width; ESL, oesophageal length; BCL, buccal capsule length; BCW, buccal capsule width; EPD, distance from anterior extremity to excretory pore; SL, spicule length; GL, gubernaculum length; V, distance from vulva to posterior extremity; T, tail length; EL, egg-length; EW, egg-width. Measurements in the descriptions are given as the ranges with means in parentheses. Voucher specimens have been deposited in the South Australian Museum (SAM 46148 and 46150 for Seal Rocks and Kanowna Island colony specimens, respectively).

\section{Molecular study}

Uncinaria specimens collected during post-mortem examinations of $A$. p. doriferus pups from Seal Rocks (n=5) and Kanowna Island (n=5) in 2007-2008 were used for molecular studies. Additional samples collected previously from A. p. doriferus $(\mathrm{n}=5)$ (collected by $\mathrm{R}$. Norman, 1993, Lady Julia Percy Island, 38²2’S, $142^{\circ} 00^{\prime}$ E, Victoria, SAM 46149), A. forsteri ( $\left.\mathrm{n}=1\right)$ (collected by R. Norman, 1993, Kangaroo Island), N. cinerea $(\mathrm{n}=1)$ (collected by R. Norman, 1994, Dangerous Reef, South Australia) and M. leonina $(n=4)$ (collected by C. Bell, 1994, Macquarie Island, 54³7’S, $158^{\circ} 51^{\prime} \mathrm{E}$, SAM 46151) were included in molecular studies. All specimens were stored in $70 \%$ ethyl alcohol or at $-70 \mathrm{C}^{\circ}$ prior to analysis.

Following repeated washes in physiological saline, total genomic DNA was extracted from individual nematodes using a standard sodium dodecyl-sulphate/proteinase $\mathrm{K}$ treatment (Gasser et al., 1993), followed by purification over Wizard Clean-Up columns (Promega). Polymerase chain reaction (PCR) amplification of the ITS-1 and ITS-2 regions was performed using NC16 (forward) and NC2 (reverse) primers (Chilton, 2004). PCR (50 $\mu$ l) was performed in $10 \mathrm{mM}$ of Tris- $\mathrm{HCl}\left(\mathrm{pH} 8.4\right.$ ), $50 \mathrm{mM}$ of $\mathrm{KCl}, 3.0 \mathrm{mM}$ of $\mathrm{MgCl}_{2}, 250 \mu \mathrm{M}$ of each dNTP, 100 pmol of each primer and $2.5 \mathrm{U}$ Taq polymerase (Promega) using the following conditions: $94^{\circ} \mathrm{C}$ for $5 \mathrm{~min}$ (initial denaturation), followed by $94^{\circ} \mathrm{C}$ for $30 \mathrm{~s}$ (denaturation), $60^{\circ} \mathrm{C}$ for $30 \mathrm{~s}$ (annealing), $72^{\circ} \mathrm{C}$ for $30 \mathrm{~s}$ (extension) 35 cycles, followed by a final extension at $72^{\circ} \mathrm{C}$ for 10 min. Aliquots $(5 \mu \mathrm{l})$ of individual PCR products were examined by standard agarose gel electrophoresis and ultraviolet transillumination. Samples with DNA of Haemonchus contortus Rudolphi, 1802 and without nematode DNA were included during amplification as 'positive' and 'negative' controls, respectively. No amplicons were detected in the negative controls.

Following purification of amplicons over spin columns (Wizard PCR Prep System, Promega), samples were subjected to automated sequencing using BigDye Terminator v.3.1 chemistry in an ABI PRISM sequencer (Applied Biosystems) according to the manufacturer's protocol. The nucleotide sequences were trimmed to a uniform span of $842 \mathrm{bp}$ and assembled manually. The resulting sequences were analyzed using the BLAST program against NCBI 
GenBank database (http://www.ncbi.nlm.nih.gov/). Sequences were compared with Uncinaria species collected from $C$. ursinus and Z. californianus using Uncinaria stenocephala Railliet, 1884 from the domestic dog Canis familiaris (Linnaeus), as an outgroup. Sequence similarity was measured through pairwise comparisons of the ITS-1 and ITS-2 sequences using the formula $\mathrm{S}=\mathrm{M} / \mathrm{L}$, where $\mathrm{S}=$ similarity, $\mathrm{M}=$ number of identical bases and $\mathrm{L}=$ total number of alignment positions over which the two specimens are compared (Chilton et al., 1995) (Table 3). Sequences from individual Uncinaria specimens have been deposited in GenBank (accession numbers: HE962175-HE962186).

\title{
Morphological study
}

\section{Uncinaria specimens from $A . p$. doriferus}

\author{
Description (Figs. 1 $\square$ 11; Table 1)
}

General. Small nematodes; body covered with numerous fine, transverse striations; anterior end bent dorsally. Mouth armed with 2 ventral, semilunar cutting plates. Two lateral amphids and 4 smaller, submedian papillae situated around mouth. Buccal capsule elongate; walls heavily sclerotised; ventral wall curved anterodorsally to form paired cutting plates. Paired, small, blunt ventral lancets arise near base of buccal capsule. Dorsal gutter present, containing duct of dorsal oesophageal gland. Oesophagus short, clavate, lining sclerotised; 3 lip-like projections surround opening of oesophagus into intestine. Nerve ring in mid-oesophageal region. Excretory pore at level of nerve ring. Deirids short, conical, at level of nerve ring.

Male [Measurements based on 7 specimens.] Total length 9.9012 .00 (11.15); maximum width $0.300 .40(0.34)$; length of oesophagus 0.871 .21 (1.06); length of buccal capsule 0.220 .26 (0.23), width of buccal capsule $0.150 .18(0.16)$; excretory pore from anterior end 0.680 .95 (0.83). Bursa with large, paired, ventro-lateral lobes; dorsal lobe very small; lateral lobes not separated from ventral lobes. Rays 2 and 3 slender, fused, reach margin of bursa. Rays 46 stouter, parallel, of equal width. Dorsal ray broad at origin; externodorsal rays (8) arising from dorsal ray at one-third length; dorsal ray digitate at tip, dividing twice to give 4 terminal digitations or, more often, inner pair re-dividing to give 6 digitations. Spicules elongate, 
0.790 .87 (0.85) long, slender, tubular, tips sharp. Gubernaculum elongate, margins irregular, length $0.100 .14(0.12)$.

Female [Measurements based on 13 specimens.] Total length 16.4524 .85 (20.79); maximum width 0.370 .49 (0.44); length of oesophagus 1.121 .53 (1.31); length of buccal capsule 0.260 .33 (0.29), width of buccal capsule $0.190 .26(0.24)$; excretory pore from anterior end 0.771 .04 (0.92). Tail short, conical, 0.200 .28 (0.25) long. Vulva in posterior half of body, 6.389 .66 (8.16) from posterior end; vulval lips conspicuous. Vagina vera short; ovejector longitudinally disposed; uteri opposed. Eggs thin-shelled, ellipsoidal, 0.100 .14 (0.12) 0.070 .09 (0.08).

\section{Remarks}

Observable differences in morphological measurements between parasites found in $A$. $p$. doriferus and parasites found in other hosts from the southern hemisphere included body length, oesophageal length and distance from the vulva to the posterior end in female worms and body length in male worms (Table 1). Observable differences between parasites from A. p. doriferus and other parasites for which molecular descriptions exist included body length, oesophageal length and the distance from the vulva to posterior extremity in females and body length, oesophageal length and spicule length in males (Table 1).

\section{Uncinaria specimens from M. leonina}

Description (Figs. 12-18; Table 1)

General. Small nematodes; body covered with numerous fine, transverse striations; anterior end bent dorsally. Mouth armed with 2 ventral, semilunar cutting plates. Two lateral amphids and 4 smaller, submedian papillae situated around mouth. Buccal capsule elongate; walls heavily sclerotised; ventral wall curved anterodorsally to form paired cutting plates. Paired, small, blunt ventral lancets arise near base of buccal capsule. Dorsal gutter present, containing duct of dorsal oesophageal gland. Oesophagus short, clavate, lining sclerotised; 3 lip-like projections surround opening of oesophagus into intestine. Nerve ring in mid-oesophageal region. Excretory pore at level of nerve ring. Deirids short, conical, at level of nerve ring. 
Male [Measurements based on 1 specimen.] Total length 8.5; maximum width 0.23; length of oesophagus 0.85 ; length of buccal capsule 0.13 , width of buccal capsule 0.09 ; excretory pore from anterior end 0.45. Bursa with large, paired, ventro-lateral lobes; dorsal lobe very small; lateral lobes not separated from ventral lobes. Rays 2 and 3 slender, fused, reach margin of bursa. Rays 46 stouter, parallel, of equal width. Dorsal ray broad at origin; externodorsal rays (8) arising from dorsal ray at one-third length; dorsal ray digitate at tip, dividing twice to give 4 terminal digitations or, more often, inner pair re-dividing to give 6 digitations. Spicules elongate, 0.47 long, slender, tubular, tips sharp. Gubernaculum elongate, margins irregular.

Female [Measurements based on 44 specimens.] Total length 20.531 .2 (25.0); maximum width 0.370 .54 (0.45); length of oesophagus 1.101 .65 (1.35); length of buccal capsule 0.200 .27 (0.24), width of buccal capsule $0.160 .22(0.20)$; excretory pore from anterior end 0.771 .04 (0.92). Tail short, conical, 0.130 .26 (0.20) long. Vulva in posterior half of body; vulval lips conspicuous. Vagina vera short; ovejector longitudinally disposed; uteri opposed. Eggs thinshelled, ellipsoidal, $0.100 .15(0.13) \quad 0.08(0.08)$.

\section{Remarks}

The description of the nematodes from M. leonina is limited by the lack of males. However, from the material available, the specimens are similar in most morphological features to other collections of Uncinaria from pinnipeds but the females are much larger than any other collections reported to date.

\section{Molecular study}

Pairwise comparison of sequence similarities (\%) of ITS-1 and ITS-2 (Table 2) showed 100\% similarity between specimens from $A$. forsteri and $N$. cinerea. Pairwise comparisons showed 99.5-99.7\% similarity of ITS-1 and 100\% similarity of ITS-2 between specimens from $A . p$. doriferus and A. forsteri / N. cinerea, which differed at only a single base at position 167 (Fig. 19). Molecular analysis revealed no sequence polymorphism in the ITS- 1 and ITS-2 regions of multiple parasites from the three Australian fur seal colonies sampled.

ITS-1 and ITS-2 sequence similarities between the nematode isolates from A. p. doriferus / A. forsteri / N. cinerea and those from Z. californianus / C. ursinus ranged from 92.6 to $97.3 \%$. 
ITS-1 and ITS-2 sequence similarities between M. leonina and all other hosts ranged from 90.7 to $97.5 \%$ (Table 2).

Fig. 19 illustrates the alignment of the ITS-1 and ITS-2 sequences of Uncinaria nematodes from the six pinniped hosts, M. leonina, A. p. doriferus, A. forsteri, $N$. cinerea, $C$. ursinus (GenBank AF217890) and Z. californianus (GenBank AF217889) using U. stenocephala (GenBank AF194145) as an outgroup. No genetic data were available for comparisons with parasites of $P$. hookeri found in New Zealand waters. Phylogenetic analysis of the data is illustrated in Fig. 20. Three clades are evident, with the Australian specimens forming one clade and potentially representing a single species, the Californian specimens a second clade, presumably represented by two species and those from M. leonina a third.

\section{Discussion}

Hookworms from A. p. doriferus were considered closely related to $U$. hamiltoni using morphological criteria as described by Baylis $(1933,1947)$, such as a relatively larger buccal capsule, a larger bursa, an annular thickening at the base of the buccal capsule, larger subventral teeth, the presence of tooth-like structures at the subdorsal angles of the capsule border, a longer oesophagus, longer spicules and a shorter antero-lateral ray relative to the other lateral rays. Metrical variation between parasites collected from hosts in the southern hemisphere, as well as parasites for which molecular data exist (Table 1) was also observed, with differences in body size, length of oesophagus, length of spicules and distance from the vulva to the tail being the most obvious. Comparisons with specimens from M. leonina were limited by the existence of only a single male among hundreds of females (SAM 34996) and the poor state of preservation of the specimens.

Differences occurred between nematodes from M. leonina, A. p. doriferus, A. forsteri and $N$. cinerea with the latter three hosts sharing a species with virtually identical ITS-1 and ITS-2 regions differing at a single base only (Table 2). Samples from A. p. doriferus were from Victoria, whereas those from A. forsteri and N. cinerea were from South Australia, a distance of several hundreds of kilometres, such that the differences may represent geographical variation. The two loci studied exhibited sets of fixed patterns of genetic characters collectively unique and exclusive to each geographical region (Australia, Antarctica, California) (Fig. 19), providing more robust evidence than sequence divergence alone for a distinct parasite taxon (Nadler, 2002) in M. leonina and in the Australian hosts A. p. doriferus, A. forsteri and N. cinerea.

With few known exceptions (Prociv \& Croese, 1996; Traub et al., 2008), hookworms tend to be host-specific parasites (Prociv \& Croese, 1996). Whether the taxon infecting A. p. 
doriferus, A. forsteri and $N$. cinerea is specific to one of these host species studied has yet to be determined. In addition, whether infection causes a detrimental impact on any southern hemisphere host remains uncertain, as occurs with infections of $U$. lucasi in C. ursinus (see Lucas, 1899) or Uncinaria species A in Z. californianus (Spraker et al., 2007). The host specificity of the nematodes from M. leonina is also unknown.

Aberrant host infection can carry implications for the conservation of a threatened host species, depending in part on the presence and extent of associated pathological impact (Lo Guidice, 2003; Zhang et al., 2008). In addition, high levels of pinniped pup morbidity and mortality have been reported both at high intensities of infections with Uncinaria spp. as well as independent of high parasitic burden (Olsen, 1958; Keyes, 1965; Mizuno, 1997; Lyons et al., 2001; Castinel et al., 2007; Spraker et al., 2007; Chilvers et al., 2009), underscoring the significance and complexity of host, pathogen and environment interactions.

It should be noted that identification of cryptic species using either morphological or molecular variation alone should be interpreted with caution (Blair et al., 1997; Andrews \& Beveridge, 1990; Chilton et al., 1995; Nolan \& Cribb, 2005). For example, in the case of the parasites from A. p. doriferus and $N$. cinerea, it may not be possible to reliably separate closely related species, especially if the number of DNA base sequence differences is small and if only a single locus, in this case ITS, is used. Additionally, in this data set, the ability to distinguish between intraspecific and interspecific variation is to some extent constrained as the molecular data were obtained from few (1 5) specimens.

Consideration of morphological, biological and molecular data together may provide for a more accurate depiction of specific status (Anderson \& Barker, 1993; Nolan \& Cribb, 2005; Blasco-Costa et al., 2010). In this instance, the current and previous observations citing morphological differences (Baylis, 1947) together with the genetic data presented here, provide compelling evidence for a distinct species of Uncinaria parasitizing M. leonina. Furthermore, the molecular data together with morphological comparisons of parasites from hosts for which parasite molecular data exist (Table 1), suggest that the parasite species present in the Australian fur seal, Australian sea lion and New Zealand fur seal in Australian waters is distinctive. No species names are being given until more comprehensive data exist for other Uncinaria spp. from various pinniped hosts and until sequence data from the Falkland Islands can confirm the identity of $U$. hamiltoni.

This paper is the first morphological and molecular description of Uncinaria sp. from pinnipeds inhabiting Australian waters. Eleven hookworm species representing four genera, Ancylostoma Dubini, 1843, Bunostomum Railliet, 1902, Necator Stiles, 1903 and Uncinaria have been recorded in Australia. The majority of these species are believed to have been recent 
arrivals, most likely introduced by humans and domestic animals (Beveridge, 2002). The only species believed to be native to the continent include the endemic Uncinaria hydromyidis Beveridge, 1980 found in the water rat (Hydromys chrysogaster Geoffroy) in north-eastern Queensland and the Uncinaria species found in A. p. doriferus, N. cinerea and A. forsteri (Beveridge, 1980). The only two native Australian Uncinaria species share as a common feature an aquatic or marine definitive host, the former of which arrived in the continent with rodents migrating from South East Asia and the second with a group of highly dispersed marine mammals (Beveridge, 1980).

Acknowledgements We wish to thank Roger Kirkwood, Tony Mitchell, Andrew Hoskins and Parks Victoria for logistical support and assistance in sample collection; Garry Anderson for statistical analysis; Robin Gasser and Matthew Nolan for molecular input; Angela Kapparis for editing assistance; Zoos Victoria, the University of Melbourne department of Veterinary Science and the Melbourne Zoo veterinary department for logistical and financial support.

\section{References}

Anderson, G. R., \& Barker, S. C. (1993). Species differentiation in the Didymozoidae (Digenea): restriction fragment length differences in internal transcribed spacer and 5.8S ribosomal DNA. International Journal for Parasitology, 23, 133-136.

Andrews, R. H., \& Beveridge, I. (1990). Apparent absence of genetic differences among species of Teladorsagia (Nematoda: Trichostrongylidae). Journal of Helminthology, 64, 290294.

Baylis, H. A. (1933). A new species of the nematode genus Uncinaria from a sea-lion, with some observations on related species. Parasitology, 25, 308-316.

Baylis, H. A. (1947). A redescription of Uncinaria lucasi Stiles, a hookworm of seals. Parasitology, 38, 160-162.

Beron-Vera, B., Crespo, E. A., Raga, J. A., \& Pedraza, S. N. (2004). Uncinaria hamiltoni (Nematoda: Ancylostomatidae) in South American sea lions, Otaria flavescens, from Northern Patagonia, Argentina. Journal of Parasitology, 90, 860-863.

Beveridge, I. (1980). Uncinaria hydromyidis sp. n. (Nematoda: Ancylostomatidae) from the Australian water rat, Hydromys chrysogaster. Journal of Parasitology, 66, 1030.

Beveridge, I. (2002). Australian hookworms (Ancylostomatoidea): a review of the species present, their distributions and biogeographical origins. Parassitologia, 44, 83-88. 
Blair, D., Agatsuma, T., Watanobe, T., Okamoto, M., \& Ito, A. (1997). Geographical genetic structure within the human lung fluke, Paragonimus westermani, detected from DNA sequences. Parasitology, 115, 411-417.

Blasco-Costa, I., Balbuena, A., Raga, J. A., Kostadinova, A., \& Olson, P. D. (2010). Molecules and morphology reveal cryptic variation among digeneans infecting sympatric mullets in the Mediterranean. Parasitology, 137, 287-302.

Botto, C., \& Mane-Garzon, F. (1975). Sobre una nueva subespecie del género Uncinaria (Nematoda, Strongyloidea) de Otaria flavescens Shaw y la especiación en el genero Uncinaria en pinnipedos americanos. Revista de Biología del Uruguay, 3, 127-141.

Castinel, A., Duignan, P. J., Pomroy, W. E., Lyons, E. T., Nadler, S. A., Dailey, M. D., Wilkinson, I. S., \& Chilvers, B. L. (2006). First report and characterization of adult Uncinaria spp. in New Zealand sea lion (Phocarctos hookeri) pups. Parasitology Research, 98, 304-309.

Castinel, A., Duignan, P. J., Lyons, E. T., Pomroy, W. E., Gibbs, N., Lopez-Villalobos, N., Chilvers, B. L., \& Wilkinson, I. S. (2007). Epidemiology of hookworm (Uncinaria spp.) infection in New Zealand (Hooker's) sea lion (Phocarctos hookeri) pups on Enderby Island, Auckland Islands (New Zealand) during the breeding seasons from 1999/2000 to 2004/2005. Parasitology Research, 101, 53-62.

Chilton, N. B., Gasser, R. B., \& Beveridge, I. (1995). Differences in a ribosomal DNA sequence of morphologically indistinguishable species within the Hypodontus macropi complex (Nematoda: Strongyloidea). International Journal for Parasitology, 25, 647-651.

Chilton, N. B. (2004). The use of ribosomal DNA markers for the identification of bursate nematodes (order Strongylida) and for the diagnosis of infections. Animal Health Research Reviews, 5, 173-187.

Chilvers, B. L., Duignan, P. J., \& Robertson, B. C. (2009). Effects of hookworms (Uncinaria sp.) on the early growth and survival of New Zealand sea lion (Phocarctos hookeri) pups. Polar Biology, 32, 295-302.

Dailey, M. D., \& Hill, B. L. (1970). A survey of metazoan parasites infecting the California (Zalophus californianus) and Steller (Eumetopias jubatus) sea lion. Bulletin of the Southern California Academy of Science, 69, 126-132.

Durette-Desset (1983). Keys to genera of the superfamily Trichostrongyloidea. In: Anderson, R. C.\& Chabaud, A. G. (Eds.) CIH keys to the nematode parasites of vertebrates. No.10. Commonwealth Agricultural Bureaux; Farnham Royal, UK, pp. 1-68. 
Gasser, R. B., Chilton, N. B., Hoste, H., \& Beveridge, I. (1993). Rapid sequencing of rDNA from single worms and eggs of parasitic helminthes. Nucleic Acids Research, 21, 25252526.

George-Nascimento, M., Lima, M., \& Ortiz, E. (1992). A case of parasite mediated competition? Phenotypic differentiation among hookworms Uncinaria sp. (Nematoda:

Ancylostomatidae) in sympatric and allopatric populations of South American sea lions Otaria bryonia, and fur seals Arctocephalus australis (Carnivora: Otariidae). Marine Biology, 112, 527-533.

Johnston, T. H., \& Mawson, P. M. (1945). Parasitic Nematodes Part 2. British, Australian and New Zealand Antarctic Research Expedition Reports, Series B, 5, 73-160.

Keyes, M. C. (1965). Pathology of the northern fur seal. Journal of the American Veterinary Medical Association, 147, 1090-1095.

Lo Giudice, K. (2003). Trophically transmitted parasites and the conservation of small populations: raccoon roundworm and the imperiled Allegheny woodrat. Conservation Biology, 17, 258-266.

Lucas, F. A. (1899). The causes of mortality among seals. In: Jordan, D. S. (Ed.), The fur seals and fur-seal islands of the North Pacific Ocean, part III. Special papers relating to the fur-seal and to the natural history of the Pribilof islands. Government Printing Office; Washington, DC, pp. 75-98.

Lyons, E. T., Delong, R. L, Melin, S. R., \& Tolliver, S. C. (1997). Uncinariasis in northern fur seals and California sea lion pups from California. Journal of Wildlife Diseases, 33, 848852.

Lyons, E. T., Delong, R. L., Gulland, F. M., Melin, S. R., Tolliver, S. C., \& Spraker, T. R. (2000). Comparative biology of Uncinaria spp. in the California sea lion (Zalophus californianus) and the Northern fur seal (Callorhinus ursinus) in California. Journal of Parasitology, 86, 1348-1352.

Lyons, E. T., Melin, S. R, Delong, R. L., Orr, A. J., Gulland, F. M., \& Tolliver, S. C. (2001). Current prevalence of adult Uncinaria spp. in northern fur seal (Callorhinus ursinus) and California sea lion (Zalophus californianus) pups on San Miguel Island, California, with notes on the biology of these hookworms. Veterinary Parasitology, 97, 309-318.

Lyons, E. T., Delong, R. L., Nadler, S. A., Laake, J. L., Orr, A. J., Delong, B. L., \& Pagan, C. (2011). Investigations of peritoneal and intestinal infections of adult hookworms (Uncinaria spp.) in northern fur seal (Callorhinus ursinus) and California sea lion (Zalophus californianus) pups on San Miguel Island, California (2003). Parasitology Research, 109, 581-589. 
Mizuno, A. (1997). Ecological study on the hookworm, Uncinaria lucasi, of northern fur seal, Callorhinus ursinus, in Bering Island, Russia. Japanese Journal of Veterinary Research, 45, 109-110.

Nadler, S. A., Adams, B. J., Lyons, E. T., Delong, R. L., \& Melin, S. R. (2000). Molecular and morphometric evidence for separate species of Uncinaria (Nematoda: Ancylostomatidae) in California sea lions (Zalophus californianus) and northern fur seals (Callorhinus ursinus). Journal of Parasitology, 86, 1099-1106.

Nadler, S. A. (2002). Species delimitation and nematode biodiversity: phylogenies rule. Nematology, 4, 620-625.

Nolan, M. J., \& Cribb, T. H. (2005). The use and implications of ribosomal DNA sequencing for the discrimination of digenean species. Advances in Parasitology, 60, 101-163.

Oliva, D. (1988). Otaria byronia (de Blainville, 1820), the valid scientific name for the southern sea lion (Carnivora: Otariidae). Journal of Natural History, 22, 767-772.

Olsen, O. W. (1958). Hookworms, Uncinaria lucasi Stiles, 1901, in fur seals, Callorhinus ursinus (Linn.), on the Pribilof Islands. Transactions of the Twenty-third North American Wildlife Conference. Washington DC: Wildlife Management Institute, 152-175.

Olsen, O. W., \& Lyons, E. T. (1965). Life cycle of Uncinaria lucasi Stiles, 1901 (Nematoda: Ancylostomatidae) of fur seals, Callorhinus ursinus Linn., on the Pribilof Islands, Alaska. Journal of Parasitology, 51, 689-700.

Prociv, P., \& Croese, J. (1996). Human enteric infection with Ancylostoma caninum: hookworms re-appraised in the light of a 'new' zoonosis. Acta Tropica, 62, 23-44.

Sepulveda, M. S., \& Alcaino, H. (1993). Fauna helmintologica en el lobo fino de Juan Fernandez, Arctocephalus philippii (Peters, 1866). Parasitologia al Dia, 17, 19-24.

Sepulveda, M. S. (1998). Hookworms (Uncinaria sp.) in Juan Fernandez fur seal pups (Arctocephalus philippii) from Alejandro Selkirk Island. Journal of Parasitology, 84, 1305-1306.

Spraker, T. R., De Long, R. L., Lyons, E. T., \& Melin, S. R. (2007). Hookworm enteritis with bacteremia in California sea lion pups on San Miguel Island. Journal of Wildlife Diseases, 43, 179-188.

Traub, R. J., Inpankaew, T., Sutthikornchai, C., Sukthana, Y., \& Thompson, R. C. (2008). PCRbased coprodiagnostic tools reveal dogs as reservoirs of zoonotic ancylostomiasis caused by Ancylostoma ceylanicum in temple communities in Bangkok. Veterinary Parasitology, 155, 67-73.

Zhang, J. S., Daszak, P., Huang, H. L., Yang, G. Y., Kilpatrick, A. M., \& Zhang, S. Y. (2008). Parasite threat to panda conservation. EcoHealth, 5, 6-9. 


\section{Captions to figures}

Figs. 1-6 Uncinaria sp. from Arctocephalus doriferus. 1. Anterior extremity, lateral view. 2. Buccal capsule, lateral view. 3. Head, apical view. 4. Interior of buccal capsule, dorsal view. 5. Female tail, lateral view. 6. Ovejector, lateral view. Abbreviations: A, amphid; CP, cephalic papilla; DG, dorsal gutter; EP, excretory pore; L, lancet; NR, nerve ring; O, ovejector; V, vagina. Scale-bars: $0.1 \mathrm{~mm}$

Figs. 7-11 Uncinaria sp. from Arctocephalus doriferus. 7. Bursa, lateral view. 8. Bursa, ventral view. 9. Spicule tips, ventral view. 10. Genital cone and gubernaculum, ventral view. 11. Dorsal ray, dorsal view. Numbering of bursal rays follows Durette-Desset (1983). Abbreviation: G: gubernaculum. Scale-bars: 7, 8, 10, $0.1 \mathrm{~mm} ; 9,11,0.01 \mathrm{~mm}$

Figs. 12-18 Uncinaria sp. from Mirounga leonina. 12. Anterior extremity, lateral view. 13. Buccal capsule, lateral view. 14. Head, apical view. 15. Ovejector, lateral view. 16. Female tail, lateral view. 17. Spicule tips, ventral view. 18. Bursa, lateral view. Scale-bars: 12, 15, 16, 18, $0.1 \mathrm{~mm} ; 13,14,17,0.01 \mathrm{~mm}$

Fig. 19 Alignment of the ITS-1 and ITS-2 from Uncinaria spp. following IUPAC nomenclature, from Mirounga leonina, Arctocephalus pusillus doriferus, Arctocephalus forsteri, Neophoca cinerea, Callorhinus ursinus (GenBank AF217890), Zalophus californianus (GenBank AF217889) and Canis familiaris (GenBank AF194145). Sequences for Uncinaria spp. from the hosts of the present study, M. leonina, A. p. doriferus, A. forsteri and N. cinerea, have been deposited in the EMBL, GenBank and DDBJ databases (Accession numbers HE962175HE962186). Period (.) notation indicates identical nucleotides, dash ( ) notation indicates deletion events

Fig. 20 Bayesian inference analysis consensus tree showing the relationships of Uncinaria spp. based on ITS1 and ITS2 sequence data. Hosts: Mirounga leonina, Arctocephalus pusillus doriferus from colonies on Kanowna Island, Lady Julia Percy Island and Seal Rocks, 
Arctocephalus forsteri, Neophoca cinerea, Callorhinus ursinus (GenBank number AF217890) and Zalophus californianus (GenBank number AF217889). AF194145 represents $U$. stenocephala from Canis familiaris. Vic=Victoria, SA=South Australia. Posterior probability values indicated at nodes

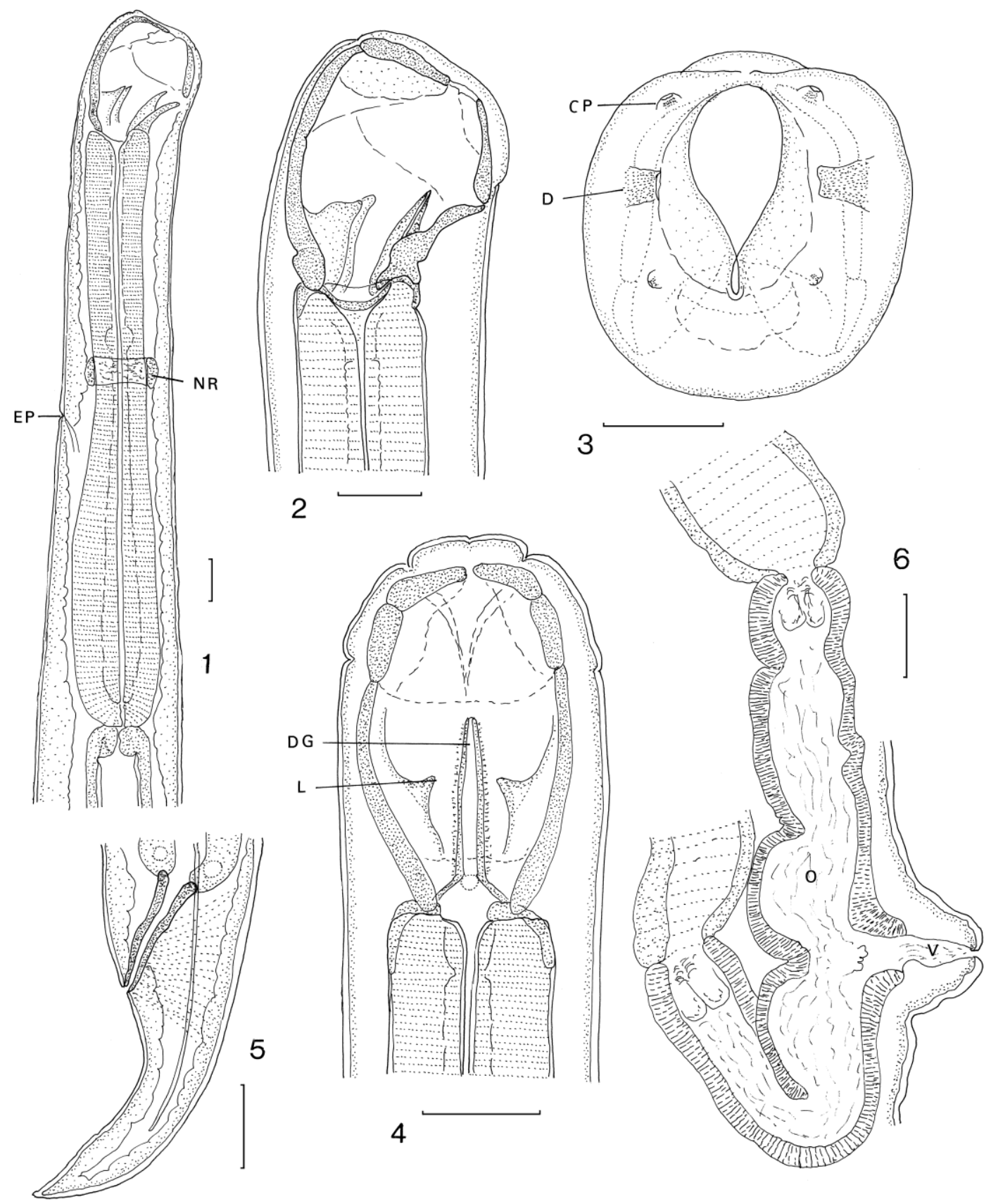



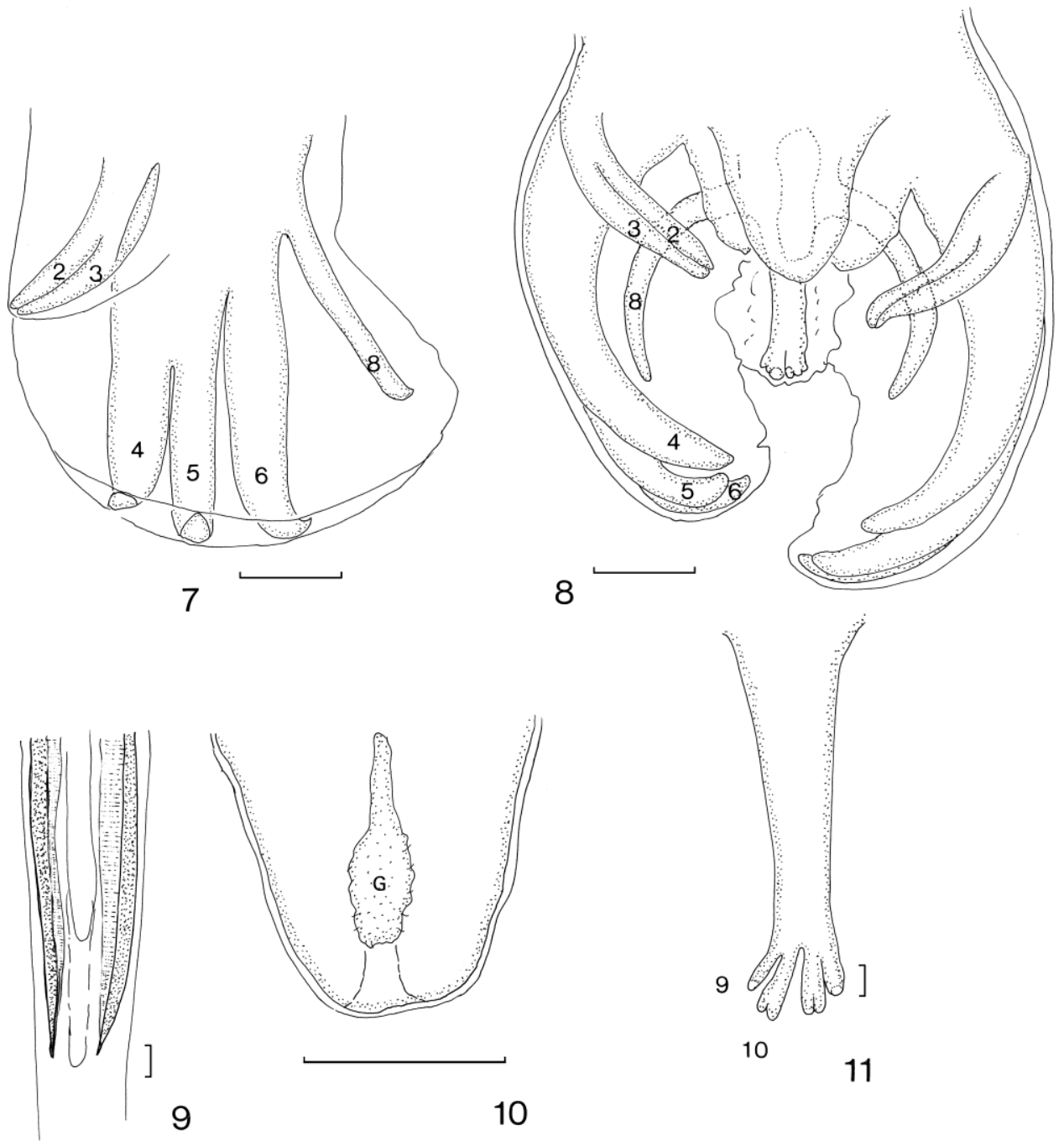

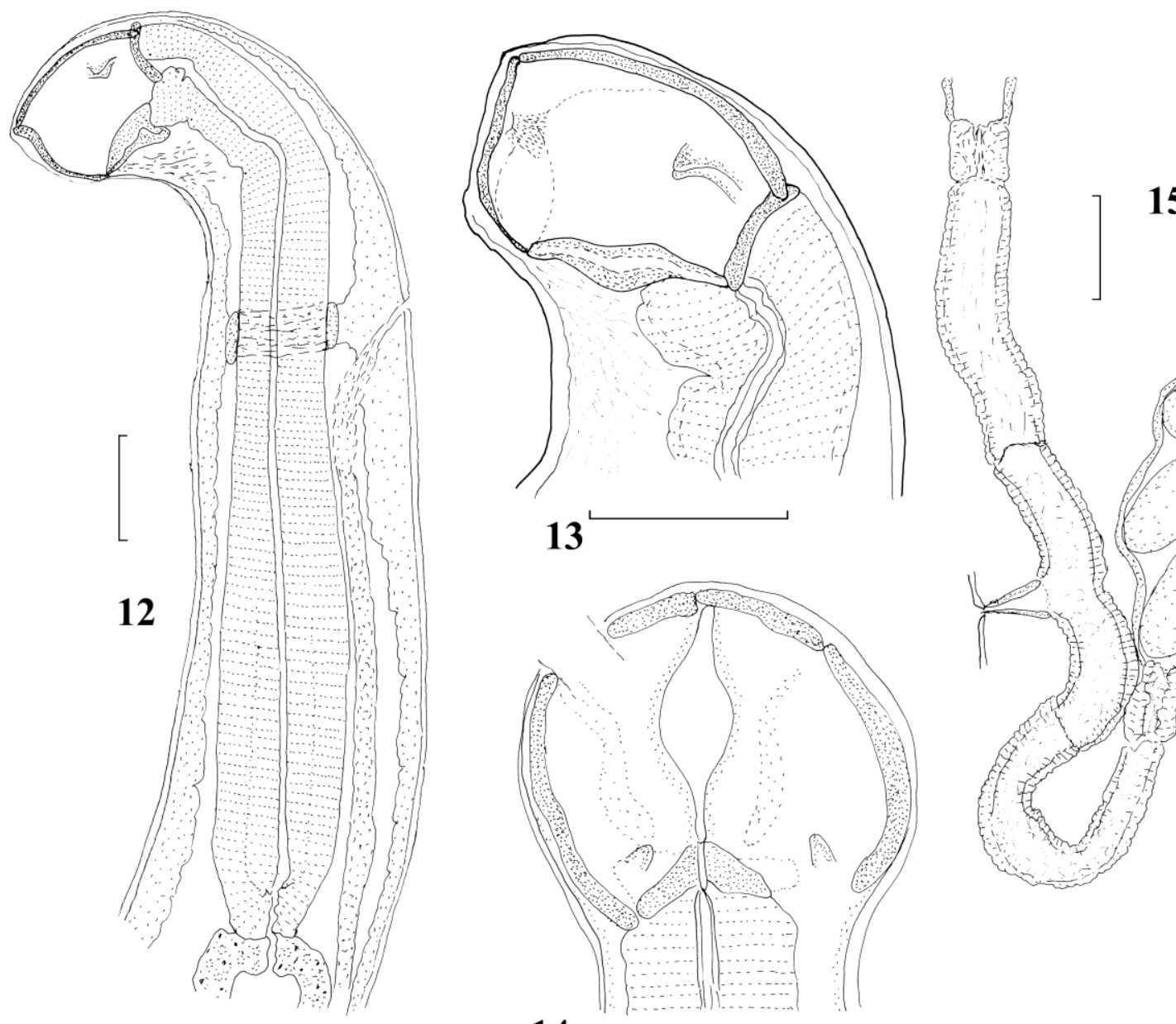

15
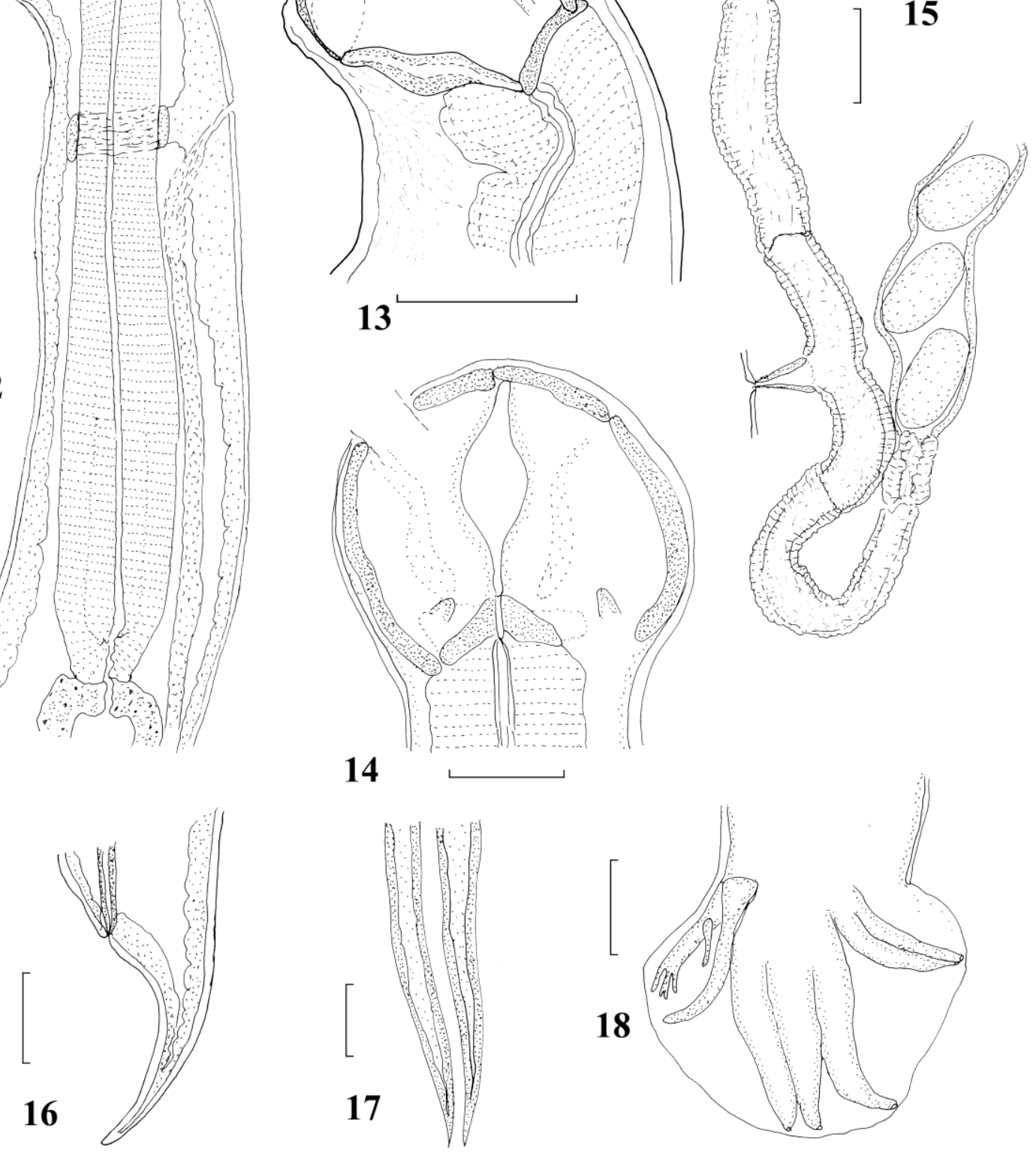


\begin{tabular}{|c|c|c|c|c|c|c|c|c|c|c|c|c|}
\hline Position \# & 18 & 76 & 83 & \multicolumn{3}{|c|}{$100-119$} & 123 & 136 & 142 & 146 & 147 & 153 \\
\hline M.leonina & $\mathrm{A}$ & $\mathrm{C}$ & $\mathrm{T}$ & \multicolumn{3}{|c|}{ AGTTTTCACGACTTTGTCGG } & $\mathrm{T}$ & A & $\mathrm{C}$ & $\mathrm{T}$ & $\mathrm{T}$ & $\mathrm{T}$ \\
\hline Ap.doriferus & . & . & . & \multicolumn{3}{|c|}{ AGTTTTCACGACTTTGTCGG } & . & . & . & -. & -- & \\
\hline Aforsteri & .- & & & \multicolumn{3}{|c|}{ AGTTTTCACGACTTTGTCGG } & & & & .- & .- & . \\
\hline N.cinerea & -- & . & . & \multicolumn{3}{|c|}{ AGTTTTCACGACTTTGTCGG } & . & . & . & -- & .- & \\
\hline C.ursinus & . & . & . & \multirow{2}{*}{\multicolumn{3}{|c|}{-}} & & & & . & .- & \\
\hline Zcalifornianus & . & 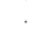 & & & & & A & & .- & . & -- & \\
\hline C.familiaris & . & $\mathrm{T}$ & c & \multicolumn{3}{|c|}{.- } & G & G & & .- & G & A \\
\hline Position \# & 167 & 172 & 194 & 211 & 226 & 243 & 263 & 268 & 269 & 278 & 289 & 300 \\
\hline M.leonina & $\mathrm{A}$ & A & $\mathrm{G}$ & $\mathrm{A}$ & $\mathrm{C}$ & $\mathrm{A}$ & $\mathrm{T}$ & $\mathrm{C}$ & $\mathrm{A}$ & $\mathrm{T}$ & $\mathrm{A}$ & $\mathrm{G}$ \\
\hline A.p.doriferus & 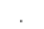 & . & . & . & . & . & & & G & . & . & $\mathrm{T}$ \\
\hline Aforsteri & C & & & & & . & . & . & G & & & $\mathrm{T}$ \\
\hline N.cinerea & C & . & . & . & . & & & & G & . & . & $\mathrm{T}$ \\
\hline C.ursinus & . & & A & & & . & . & & G & & & $\mathrm{T}$ \\
\hline Zcalifornianus & . & . & A & . & A & & & & G & . & . & $\mathrm{T}$ \\
\hline C.familiaris & . & C & . & G & . & G & $\mathrm{C}$ & $\mathrm{T}$ & . & G & G & . \\
\hline Position \# & 301 & 347 & 352 & 353 & 354 & 367 & 386 & 388 & 389 & 392 & 401 & 412 \\
\hline M.leonina & $\mathrm{T}$ & $\mathrm{C}$ & G & $\mathrm{C}$ & A & $\mathrm{A}$ & $\mathrm{C}$ & $\mathrm{C}$ & G & $\mathrm{T}$ & G & $\mathrm{C}$ \\
\hline Ap.doriferus & . & $\mathrm{T}$ & A & . & . & & & & A & G & . & $\mathrm{T}$ \\
\hline Aforsteri & & $\mathrm{T}$ & A & & & . & . & . & A & G & & $\mathrm{T}$ \\
\hline N.cincrea & . & $\mathrm{T}$ & A & . & . & & & & A & G & . & $\mathrm{T}$ \\
\hline C.ursinus & . & $\mathrm{T}$ & A & . & . & & & & A & G & . & $\mathrm{T}$ \\
\hline Zcalifornianus & & $\mathrm{T}$ & A & & & & & & A & G & A & $\mathrm{T}$ \\
\hline C.familiaris & C & & & $\mathrm{T}$ & G & G & G & $\mathrm{T}$ & & & & $\mathrm{T}$ \\
\hline Position \# & 415 & 596 & 601 & 615 & 628 & 635 & 649 & 667 & 671 & 672 & 673 & 675 \\
\hline M.leonina & $\mathrm{C}$ & $\mathrm{T}$ & A & A & $\mathrm{T}$ & C & $\mathrm{C}$ & A & G & $\mathrm{C}$ & G & $\mathrm{T}$ \\
\hline Ap.doriferus & . & . & . & G & G & $\mathrm{T}$ & $\mathrm{T}$ & G & . & . & $\mathrm{T}$ & . \\
\hline Aforsteri & & & & G & G & $\mathrm{T}$ & $\mathrm{T}$ & G & & & $\mathrm{T}$ & \\
\hline N.cinerea & . & & . & G & G & $\mathrm{T}$ & $\mathrm{T}$ & G & & . & $\mathrm{T}$ & . \\
\hline C.ursinus & & C & & & G & $\mathrm{T}$ & $\mathrm{T}$ & G & & & $\mathrm{T}$ & \\
\hline Zcalifornianus & $\mathrm{T}$ & C & . & G & G & $\mathrm{T}$ & $\mathrm{T}$ & G & & & $T$ & . \\
\hline C.familiaris & . & C & G & . & . & $\mathrm{T}$ & . & G & C & G & $\mathrm{T}$ & -- \\
\hline Position \# & 676 & 680 & 683 & 684 & 685 & 686 & 691 & 694 & 700 & 708 & 713 & 716 \\
\hline M.leonina & A & A & $\mathrm{T}$ & A & G & $\mathrm{T}$ & $\mathrm{C}$ & $\mathrm{C}$ & A & A & G & $\mathrm{C}$ \\
\hline Ap.doriferus & . & G & & G & A & C & $\mathrm{T}$ & & & & A & A \\
\hline Aforsteri & . & G & . & G & A & C & $\mathrm{T}$ & . & & & A & A \\
\hline N.cinerea & . & G & . & G & A & C & $\mathrm{T}$ & & & & A & A \\
\hline C.ursinus & . & G & . & G & A & $\mathrm{C}$ & $\mathrm{T}$ & $\mathrm{T}$ & & & A & A \\
\hline Zcalifornianus & & G & A & G & A & C & $\mathrm{T}$ & $\mathrm{T}$ & & & A & A \\
\hline C.familiaris & G & G & . & . & . & & $\mathrm{T}$ & & G & G & . & . \\
\hline Position \# & 727 & 731 & 733 & 734 & 736 & 740 & 741 & 748 & 750 & 755 & 760 & 767 \\
\hline M.leonina & $\mathrm{T}$ & G & A & A & $\mathrm{T}$ & $\mathrm{T}$ & G & $\mathrm{T}$ & A & G & G & $\mathrm{A}$ \\
\hline Ap.doriferus & . & A & G & . & C & C & & & . & . & . & G \\
\hline Aforsteri & & A & G & & C & $\mathrm{C}$ & . & . & & & & G \\
\hline N.cinerea & : & A & G & & C & C & & & . & . & . & G \\
\hline C.ursinus & & A & G & $\mathrm{T}$ & C & . & . & A & & & & G \\
\hline Zcalifornianus & & A & G & $\mathrm{T}$ & C & & & A & . & & . & G \\
\hline C.familiaris & C & A & & & & c & A & . & G & $\mathrm{T}$ & A & G \\
\hline Position \# & 787 & 788 & & & & & & & & & & \\
\hline M.leonina & $\mathrm{T}$ & $\mathrm{G}$ & & & & & & & & & & \\
\hline Ap.doriferus & & C & & & & & & & & & & \\
\hline Aforsteri & . & $\mathrm{C}$ & & & & & & & & & & \\
\hline N.cinerea & & $\mathrm{C}$ & & & & & & & & & & \\
\hline C.ursinus & & C & & & & & & & & & & \\
\hline Zcalifornianus & . & C & & & & & & & & & & \\
\hline C.familiaris & C & C & & & & & & & & & & \\
\hline
\end{tabular}




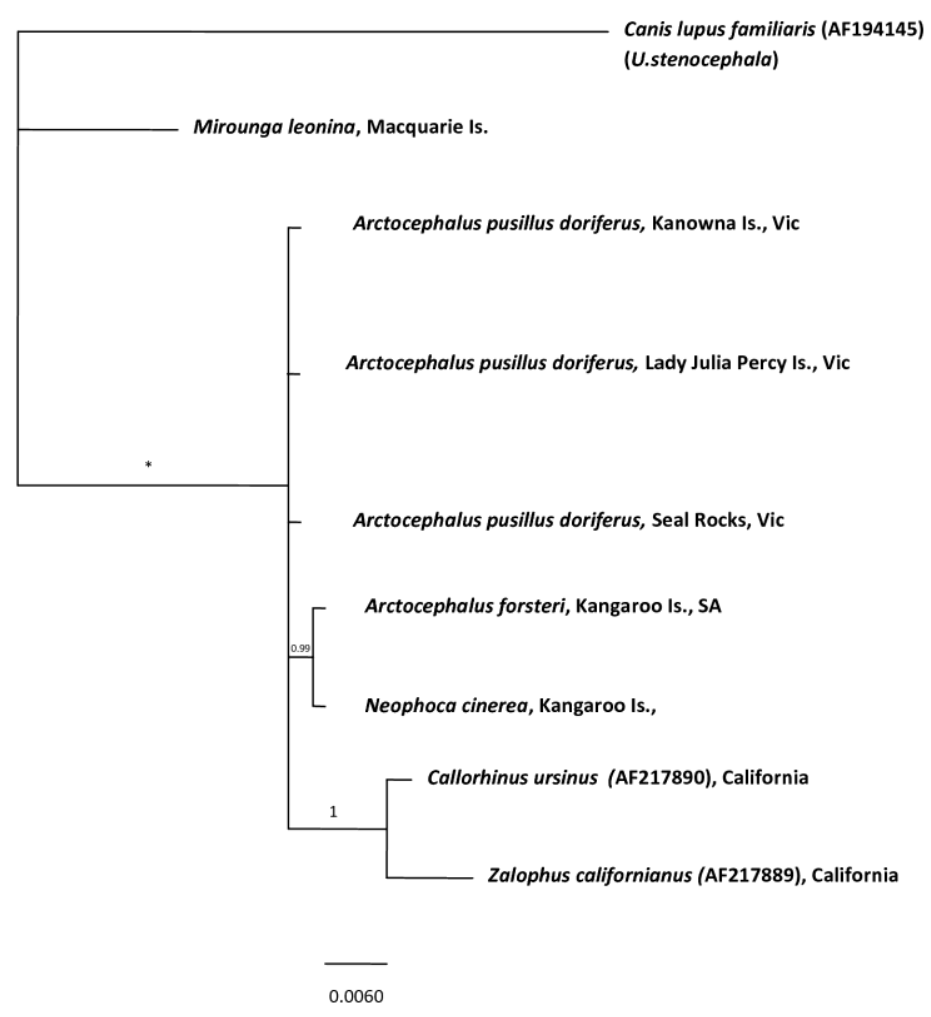

Table 1 Morphometric data (measurements in $\mathrm{mm}$ ) for Uncinaria spp. infecting pinniped hosts from the southern hemisphere. Obvious differences in bold. Abbreviations: DR, Dangerous reef 
colony; KI, Kangaroo Island colony; PI, Possession Island, Crozets colony

\begin{tabular}{|c|c|c|c|c|c|c|c|c|c|c|c|}
\hline $\begin{array}{l}\text { Parasi } \\
\text { te }\end{array}$ & $\begin{array}{l}\text { Uncinari } \\
a \text { sp. }\end{array}$ & $\begin{array}{l}\text { Uncinar } \\
\text { ia sp. }\end{array}$ & $\begin{array}{l}\text { Uncina } \\
\text { ria sp. }\end{array}$ & $\begin{array}{l}\text { Uncin } \\
\text { aria } \\
\text { sp. }\end{array}$ & $\begin{array}{l}\text { Uncinar } \\
\text { ia sp. }\end{array}$ & $\begin{array}{l}\text { Uncinari } \\
\text { a } \\
\text { hamitoni }\end{array}$ & $\begin{array}{l}\text { Uncina } \\
\text { ria } \mathrm{cf} . \\
\text { lucasi }\end{array}$ & $\begin{array}{l}\text { Uncina } \\
\text { ria } \mathrm{cf} . \\
\text { lucasi }\end{array}$ & $\begin{array}{l}\text { Uncinar } \\
\text { ia cf. } \\
\text { lucasi }\end{array}$ & $\begin{array}{l}\text { Uncinari } \\
a \text { sp. }\end{array}$ & $\begin{array}{l}\text { Uncin } \\
\text { aria } \\
\text { sp. }\end{array}$ \\
\hline Host & $\begin{array}{l}\text { A. p. } \\
\text { doriferus }\end{array}$ & $\begin{array}{l}N . \\
\text { cinerea } \\
(\mathrm{DR} \& \\
\mathrm{KI})^{*}\end{array}$ & $\begin{array}{l}\text { M. } \\
\text { leonina } \\
(\mathrm{PI})\end{array}$ & $\begin{array}{l}\text { A. } \\
\text { forste } \\
\text { ri } \\
(\mathrm{KI})\end{array}$ & $\begin{array}{l}P . \\
\text { hookeri }\end{array}$ & $\begin{array}{l}\text { O. } \\
\text { flavesce } \\
n s^{* * *}\end{array}$ & $\begin{array}{l}O . \\
\text { byronia } \\
\text { (Chile) }\end{array}$ & $\begin{array}{l}O . \\
\text { byronia } \\
\text { (Urugu } \\
\text { ay) }\end{array}$ & $\begin{array}{l}\text { A. } \\
\text { australi } \\
S\end{array}$ & $\begin{array}{l}Z . \\
\text { californi } \\
\text { anus }\end{array}$ & $\begin{array}{l}C . \\
\text { ursinu } \\
s \\
\text { (Alask } \\
\text { a \& } \\
\text { Califor } \\
\text { nia }^{*}{ }^{*}\end{array}$ \\
\hline \multirow[t]{2}{*}{$\begin{array}{l}\text { Refere } \\
\text { nce }\end{array}$} & $\begin{array}{l}\text { Present } \\
\text { study }\end{array}$ & $\begin{array}{l}\text { Present } \\
\text { study }\end{array}$ & $\begin{array}{l}\text { Present } \\
\text { study }\end{array}$ & $\begin{array}{l}\text { Prese } \\
\text { nt } \\
\text { study }\end{array}$ & $\begin{array}{l}\text { Castinel } \\
\text { et al. } \\
(2006)\end{array}$ & $\begin{array}{l}\text { Beron- } \\
\text { Vera et } \\
\text { al. } \\
(2004)\end{array}$ & $\begin{array}{l}\text { George } \\
- \\
\text { Nascim } \\
\text { ento et } \\
\text { al. } \\
\text { (1992) }\end{array}$ & $\begin{array}{l}\text { George } \\
- \\
\text { Nascim } \\
\text { ento et } \\
\text { al. } \\
\text { (1992) }\end{array}$ & $\begin{array}{l}\text { George- } \\
\text { Nascim } \\
\text { ento et } \\
\text { al. } \\
(1992)\end{array}$ & $\begin{array}{l}\text { Nadler et } \\
\text { al. } \\
(2000)\end{array}$ & $\begin{array}{l}\text { Nadler } \\
\text { et al. } \\
(2000)\end{array}$ \\
\hline & $\begin{array}{l}\text { Mean } \\
\text { (Range) }\end{array}$ & $\begin{array}{l}\text { Mean } \\
\text { (Range) }\end{array}$ & $\begin{array}{l}\text { Mean } \\
\text { (Range }\end{array}$ & & $\begin{array}{l}\text { Mean } \\
\text { (Range) }\end{array}$ & $\begin{array}{l}\text { Mean } \\
\text { (Range) }\end{array}$ & Range & Range & Range & $\begin{array}{l}\text { Mean } \\
\text { (Range) }\end{array}$ & $\begin{array}{l}\text { Mean } \\
\text { (Rang } \\
\text { e) }\end{array}$ \\
\hline $\begin{array}{l}\text { Femal } \\
\text { es }\end{array}$ & $\mathrm{n}=13$ & $\mathrm{n}=60$ & $\begin{array}{l}n=40-4 \\
4\end{array}$ & $\mathrm{n}=1$ & $\mathrm{n}=11$ & $n=30$ & $\mathrm{n}=9$ & $\mathrm{n}=12$ & $\mathrm{n}=30$ & $n=25$ & $\mathrm{n}=50$ \\
\hline BL & $\begin{array}{l}20.79 \\
(16.45-2 \\
4.85)\end{array}$ & $\begin{array}{l}15.7 \\
(12.9-1 \\
8.3)\end{array}$ & $\begin{array}{l}25 \\
(20.5- \\
31.2)\end{array}$ & 15.8 & $\begin{array}{l}10.35 \\
(7.20-1 \\
2.30)\end{array}$ & $\begin{array}{l}11.37 \\
(5.36-1 \\
7.2)\end{array}$ & $\begin{array}{l}2.98-7 . \\
69\end{array}$ & $\begin{array}{l}9.70-1 \\
3.50\end{array}$ & $\begin{array}{l}16.20-1 \\
8.20\end{array}$ & $\begin{array}{l}12.61 \\
(11.06-1 \\
3.79)\end{array}$ & $\begin{array}{l}11.66 \\
(9.48- \\
13.83)\end{array}$ \\
\hline MBW & $\begin{array}{l}0.44 \\
(0.37-0 . \\
49)\end{array}$ & $\begin{array}{l}0.48 \\
(0.41-0 . \\
55)\end{array}$ & $\begin{array}{l}0.45 \\
(0.37- \\
0.54)\end{array}$ & 0.52 & - & - & $\begin{array}{l}0.20-0 . \\
46\end{array}$ & $\begin{array}{l}0.35-0 . \\
43\end{array}$ & $\begin{array}{l}0.50-0 . \\
62\end{array}$ & $\begin{array}{l}0.41 \\
(0.35-0 . \\
54)\end{array}$ & $\begin{array}{l}0.38 \\
(0.30- \\
0.44)\end{array}$ \\
\hline ESL & $\begin{array}{l}1.31 \\
(1.12-1 . \\
53)\end{array}$ & $\begin{array}{l}1.19 \\
(1.00-1 . \\
34)\end{array}$ & $\begin{array}{l}1.35 \\
(1.10- \\
1.65)\end{array}$ & 1.25 & $\begin{array}{l}1.07 \\
(0.99-1 . \\
16)\end{array}$ & $\begin{array}{l}1.15 \\
(0.82-1 . \\
34)\end{array}$ & $\begin{array}{l}0.67-1 . \\
06\end{array}$ & $\begin{array}{l}1.08-1 . \\
20\end{array}$ & $\begin{array}{l}1.18-1 . \\
39\end{array}$ & $\begin{array}{l}0.83 \\
(0.82-0 . \\
84)\end{array}$ & $\begin{array}{l}0.82 \\
(0.80- \\
0.84)\end{array}$ \\
\hline BCL & $\begin{array}{l}0.29 \\
(0.26-0 . \\
33)\end{array}$ & $\begin{array}{l}0.29 \\
(0.22-0 . \\
32)\end{array}$ & $\begin{array}{l}0.24 \\
(0.20- \\
0.27)\end{array}$ & 0.3 & $\begin{array}{l}0.23 \\
(0.22-0 . \\
25)\end{array}$ & $\begin{array}{l}0.28 \\
(0.21-0 . \\
34)\end{array}$ & $\begin{array}{l}0.18-0 . \\
26\end{array}$ & $\begin{array}{l}0.25-0 . \\
30\end{array}$ & $\begin{array}{l}0.25-0 . \\
30\end{array}$ & $\begin{array}{l}0.24 \\
(0.22-0 . \\
27)\end{array}$ & $\begin{array}{l}0.22 \\
(0.17- \\
0.26)\end{array}$ \\
\hline $\mathrm{BCW}$ & $\begin{array}{l}0.24 \\
(0.19-0 . \\
26)\end{array}$ & $\begin{array}{l}0.22 \\
(0.18-0 . \\
25)\end{array}$ & $\begin{array}{l}0.20 \\
(0.16- \\
0.22)\end{array}$ & 0.22 & $\begin{array}{l}0.19 \\
(0.16- \\
0.23)\end{array}$ & $\begin{array}{l}0.24 \\
(0.20-0 . \\
31)\end{array}$ & - & $\begin{array}{l}0.22-0 . \\
25\end{array}$ & $\begin{array}{l}0.21-0 . \\
25\end{array}$ & - & - \\
\hline EPD & $\begin{array}{l}0.92 \\
(0.77-01 \\
.04)\end{array}$ & $\begin{array}{l}0.76 \\
(0.60-1 . \\
00)\end{array}$ & $\begin{array}{l}0.64 \\
(0.48- \\
0.82)\end{array}$ & 0.69 & - & - & - & - & - & - & - \\
\hline $\mathbf{V}$ & $\begin{array}{l}8.16 \\
(6.38-9 . \\
66)\end{array}$ & - & - & - & $\begin{array}{l}4.01 \\
(3.19-4 . \\
84)\end{array}$ & $\begin{array}{l}4.33 \\
(2.13-6 . \\
62)\end{array}$ & $\begin{array}{l}1.15-3 . \\
08\end{array}$ & $\begin{array}{l}3.23-5 . \\
00\end{array}$ & $\begin{array}{l}5.60-7 . \\
82\end{array}$ & $\begin{array}{l}4.55 \\
(3.48-5 . \\
53)\end{array}$ & $\begin{array}{l}4.66 \\
(3.44- \\
5.93)\end{array}$ \\
\hline $\mathrm{T}$ & $\begin{array}{l}0.25 \\
(0.20-0 . \\
28)\end{array}$ & $\begin{array}{l}0.21 \\
(0.15-0 . \\
29)\end{array}$ & $\begin{array}{l}0.20 \\
(0.13- \\
0.26)\end{array}$ & 0.16 & $\begin{array}{l}0.20 \\
(0.16-0 . \\
23)\end{array}$ & - & - & - & - & $\begin{array}{l}0.21 \\
(0.16-0 . \\
28)\end{array}$ & $\begin{array}{l}0.23 \\
(0.16- \\
0.30)\end{array}$ \\
\hline EL & $\begin{array}{l}0.12 \\
(0.10-0 . \\
14)\end{array}$ & $\begin{array}{l}0.13 \\
(0.12-0 . \\
14)\end{array}$ & $\begin{array}{l}0.13 \\
(0.10- \\
0.50)\end{array}$ & 0.14 & $\begin{array}{l}0.13-0 . \\
14\end{array}$ & $\begin{array}{l}0.12 \\
(0.10-0 . \\
14)\end{array}$ & 0.09 & $\begin{array}{l}0.10- \\
0.12\end{array}$ & $\begin{array}{l}0.10-0 . \\
15\end{array}$ & - & - \\
\hline EW & $\begin{array}{l}0.08 \\
(0.07-0 . \\
09)\end{array}$ & $\begin{array}{l}0.08 \\
(0.07-0 . \\
09)\end{array}$ & 0.08 & 0.08 & $\begin{array}{l}0.072-0 \\
.081\end{array}$ & $\begin{array}{l}0.07 \\
(0.04-0 . \\
10)\end{array}$ & 0.06 & $\begin{array}{l}0.07-0 . \\
09\end{array}$ & $\begin{array}{l}0.08-0 . \\
09\end{array}$ & - & - \\
\hline Males & $\mathrm{n}=7$ & $\mathrm{n}=60$ & $\mathrm{n}=1$ & $\mathrm{n}=1$ & $\mathrm{n}=8$ & $\mathrm{n}=29$ & $n=3$ & $\mathrm{n}=9$ & $n=30$ & $\mathrm{n}=25$ & $\mathrm{n}=50$ \\
\hline BL & $\begin{array}{l}11.15 \\
(9.90-12 \\
.00)\end{array}$ & $\begin{array}{l}10.15 \\
(9.00-1 \\
1.80)\end{array}$ & 8.5 & 9.2 & $\begin{array}{l}6.82 \\
(5.00-9 . \\
20)\end{array}$ & $\begin{array}{l}7.85 \\
(4.88-1 \\
0.64)\end{array}$ & $\begin{array}{l}3.08-4 . \\
81\end{array}$ & $\begin{array}{l}8.06-1 \\
0.50\end{array}$ & $\begin{array}{l}10.30-1 \\
2.30\end{array}$ & $\begin{array}{l}8.33 \\
(6.52-10 \\
.29)\end{array}$ & $\begin{array}{l}7.02 \\
(5.61- \\
8.69)\end{array}$ \\
\hline MBW & $\begin{array}{l}0.34 \\
(0.30-0 . \\
40)\end{array}$ & $\begin{array}{l}0.35 \\
(0.30-0 . \\
41)\end{array}$ & 0.23 & 0.35 & - & - & $\begin{array}{l}0.15-0 . \\
29\end{array}$ & $\begin{array}{l}0.33-0 . \\
45\end{array}$ & $\begin{array}{l}0.40-0 . \\
50\end{array}$ & $\begin{array}{l}0.32 \\
(0.24-0 . \\
36)\end{array}$ & $\begin{array}{l}0.30 \\
(0.24- \\
0.35)\end{array}$ \\
\hline ESL & 1.06 & 1.04 & 0.85 & 1.1 & 0.91 & 1.09 & $0.53-0$ & $1.05-1$ & $1.03-1$ & 0.81 & 0.81 \\
\hline
\end{tabular}




\begin{tabular}{|c|c|c|c|c|c|c|c|c|c|c|c|}
\hline & $\begin{array}{l}(0.87-1 . \\
21)\end{array}$ & $\begin{array}{l}(0.86-1 . \\
30)\end{array}$ & & & $\begin{array}{l}(0.86-0 . \\
99)\end{array}$ & $\begin{array}{l}(0.79-1 . \\
83)\end{array}$ & 76 & 13 & 13 & $\begin{array}{l}(0.79-0 . \\
82)\end{array}$ & $\begin{array}{l}(0.74- \\
0.95)\end{array}$ \\
\hline BCL & $\begin{array}{l}0.23 \\
(0.22-0 . \\
26)\end{array}$ & $\begin{array}{l}0.23 \\
(0.20-0 . \\
26)\end{array}$ & 0.13 & 0.23 & $\begin{array}{l}0.20 \\
(0.19-0 . \\
21)\end{array}$ & $\begin{array}{l}0.24 \\
(0.21-0 . \\
28)\end{array}$ & $\begin{array}{l}0.18-0 . \\
25\end{array}$ & $\begin{array}{l}0.21-0 . \\
24\end{array}$ & $\begin{array}{l}0.20-0 . \\
25\end{array}$ & $\begin{array}{l}0.20 \\
(0.17-0 . \\
21)\end{array}$ & $\begin{array}{l}0.19 \\
(0.16- \\
0.23)\end{array}$ \\
\hline $\mathrm{BCW}$ & $\begin{array}{l}0.16 \\
(0.15-0 . \\
18)\end{array}$ & $\begin{array}{l}0.16 \\
(0.12-0 . \\
19)\end{array}$ & 0.09 & 0.15 & $\begin{array}{l}0.17 \\
(0.15-0 . \\
19)\end{array}$ & $\begin{array}{l}0.19 \\
(0.14-0 . \\
24)\end{array}$ & - & $\begin{array}{l}0.17-0 . \\
20\end{array}$ & $\begin{array}{l}0.17-0 . \\
20\end{array}$ & - & - \\
\hline EPD & $\begin{array}{l}0.83 \\
(0.68-0 . \\
95)\end{array}$ & $\begin{array}{l}0.71 \\
(0.55-0 . \\
83)\end{array}$ & 0.45 & 0.56 & - & - & - & - & - & - & - \\
\hline SL & $\begin{array}{l}0.85 \\
(0.79-0 . \\
87)\end{array}$ & $\begin{array}{l}0.75 \\
(0.64-0 . \\
87)\end{array}$ & 0.47 & 0.8 & $\begin{array}{l}0.69 \\
(0.62-0 . \\
74)\end{array}$ & $\begin{array}{l}0.89 \\
(0.57-1 . \\
05)\end{array}$ & $\begin{array}{l}0.67-1 . \\
06\end{array}$ & $\begin{array}{l}0.91-1 . \\
02\end{array}$ & $\begin{array}{l}0.75-1 . \\
00\end{array}$ & $\begin{array}{l}0.69 \\
(0.62-0 . \\
76)\end{array}$ & $\begin{array}{l}0.49 \\
(0.41- \\
0.62)\end{array}$ \\
\hline GL & $\begin{array}{l}0.12 \\
(0.10-0 . \\
14)\end{array}$ & $\begin{array}{l}0.10 \\
(0.08-0 . \\
14)\end{array}$ & - & 0.12 & - & - & - & - & - & - & - \\
\hline
\end{tabular}

\footnotetext{
*Values for nematodes from the two colonies combined due to no observable differences.

${ }^{* *}$ The South American sea lion $O$. flavescens is a synonym of O. byronia (see Oliva, 1988).
}

Table 2 Pairwise comparison of sequence similarities (\%) of ITS-1 (above diagonal) and ITS-2 (below diagonal). Sequenced isolates labelled after hosts/localities as follows: Mirounga leonina (ML); Arctocephalus pusillus doriferus from the colonies Kanowna Island (KAN), Lady Julia Percy Island (LJP) and Seal Rocks (SR); Arctocephalus forsteri (AF); Neophoca cinerea (NC); Callorhinus ursinus (GenBank AF217890) (CU); Zalophus californianus (GenBank AF217889) (ZC). Outgroup: Uncinaria stenocephala (GenBank AF194145) (US)

\begin{tabular}{ccccccccccc}
\hline & ML & KAN & LJP & SR & AF & NC & CU & ZC & US \\
\hline ML & & 97.5 & 97.5 & 97.5 & 97.2 & 97.2 & 91.8 & 90.7 & 88.5 \\
KAN & 91.9 & & 100 & 100 & 99.5 & 99.7 & 93.7 & 92.6 & 87.1 \\
LJP & 91.9 & 100 & & 100 & 99.5 & 99.7 & 93.7 & 92.6 & 87.1 \\
SR & 91.9 & 100 & 100 & & 99.5 & 99.7 & 93.7 & 92.6 & 87.1 \\
AF & 91.9 & 100 & 100 & 100 & & 100 & 93.4 & 92.6 & 86.8 \\
NC & 91.9 & 100 & 100 & 100 & 100 & & 93.4 & 92.6 & 86.8 \\
CU & 91.0 & 97.3 & 97.3 & 97.3 & 97.3 & 97.3 & & 98.9 & 92.6 \\
ZC & 91.0 & 97.3 & 97.3 & 97.3 & 97.3 & 97.3 & 99.1 & & 91.5 \\
US & 90.6 & 89.2 & 89.2 & 89.2 & 89.2 & 89.2 & 88.3 & 87.4 & \\
\hline
\end{tabular}




\section{University Library}

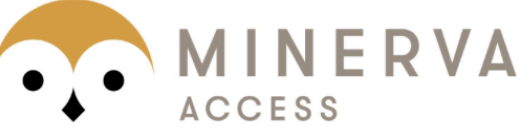

A gateway to Melbourne's research publications

Minerva Access is the Institutional Repository of The University of Melbourne

Author/s:

Ramos, P;Lynch, M;Hu, M;Arnould, JPY;Norman, R;Beveridge, I

Title:

Morphometric and molecular characterization of the species of Uncinaria Frolich, 1789

(Nematoda) parasitic in the Australian fur seal Arctocephalus pusillus doriferus (Schreber), with notes on hookworms in three other pinniped hosts

Date:

2013-05-01

Citation:

Ramos, P., Lynch, M., Hu, M., Arnould, J. P. Y., Norman, R. \& Beveridge, I. (2013).

Morphometric and molecular characterization of the species of Uncinaria Frolich, 1789

(Nematoda) parasitic in the Australian fur seal Arctocephalus pusillus doriferus (Schreber), with notes on hookworms in three other pinniped hosts. SYSTEMATIC PARASITOLOGY, 85 (1), pp.65-78. https://doi.org/10.1007/s11230-013-9407-x.

Persistent Link:

http://hdl.handle.net/11343/282886 